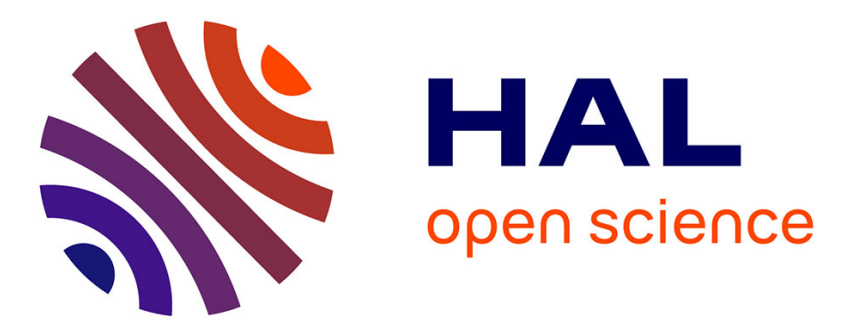

\title{
Influence of the Stretching on the Ionic Conductivity of Solid Polymer Electrolyte.
}

Roselyne Jeanne-Brou, Gilles de Moor, Nicolas Charvin, Jonathan Deseure, Flandin Lionel, Renaud Bouchet, Didier Devaux

\section{- To cite this version:}

Roselyne Jeanne-Brou, Gilles de Moor, Nicolas Charvin, Jonathan Deseure, Flandin Lionel, et al.. Influence of the Stretching on the Ionic Conductivity of Solid Polymer Electrolyte.. 238th Meeting of the Electrochemical Society - PRiME 2020 meeting, Oct 2020, Honolulu, France. hal-02979508

\section{HAL Id: hal-02979508 \\ https://hal.science/hal-02979508}

Submitted on 13 Nov 2020

HAL is a multi-disciplinary open access archive for the deposit and dissemination of scientific research documents, whether they are published or not. The documents may come from teaching and research institutions in France or abroad, or from public or private research centers.
L'archive ouverte pluridisciplinaire HAL, est destinée au dépôt et à la diffusion de documents scientifiques de niveau recherche, publiés ou non, émanant des établissements d'enseignement et de recherche français ou étrangers, des laboratoires publics ou privés. 
